\title{
Potential Probiotic Strains of Saccharomyces and Non-Saccharomyces: Functional and Biotechnological Characteristics
}

\author{
Pilar Fernández-Pacheco ${ }^{1, *}$, Cristina Pintado ${ }^{2} \mathbb{D}$, Ana Briones Pérez ${ }^{1}$ (D) and María Arévalo-Villena ${ }^{1}$ \\ 1 Analytical Chemistry and Food Technology Department, Faculty of Chemical Sciences and Technologies, \\ Castilla-La Mancha University, 13071 Ciudad Real, Spain; Ana.Briones@uclm.es (A.B.P.); \\ Maria.Arevalo@uclm.es (M.A.-V.) \\ 2 Inorganic Chemistry, Organic Chemistry and Biochemistry Department, Castilla-La Mancha University, \\ 45071 Toledo, Spain; Cristina.Pintado@uclm.es \\ * Correspondence: Pilar.FRodriguez@uclm.es
}

Citation: Fernández-Pacheco, P.; Pintado, C.; Briones Pérez, A.; Arévalo-Villena, M. Potential Probiotic Strains of Saccharomyces and Non-Saccharomyces: Functional and Biotechnological Characteristics. J. Fungi 2021, 7, 177. https://doi.org/ 10.3390/jof7030177

Academic Editor: Laurent Dufossé

Received: 4 February 2021

Accepted: 25 February 2021

Published: 2 March 2021

Publisher's Note: MDPI stays neutral with regard to jurisdictional claims in published maps and institutional affiliations.

Copyright: (c) 2021 by the authors. Licensee MDPI, Basel, Switzerland. This article is an open access article distributed under the terms and conditions of the Creative Commons Attribution (CC BY) license (https:// creativecommons.org/licenses/by/ $4.0 /)$.
Abstract: Due to the evident demand for probiotic microorganisms, a growing number of scientific studies have involved the preliminary selection of new strains, but deeper studies for knowing specific functional and biotechnological properties are needed. In the present work, twenty yeasts (Saccharomyces and non-Saccharomyces) with potential probiotic characteristics, selected in previous works, were evaluated. The following assays were realized: adhesion to Caco-2/TC7 cells, prebiotic metabolisms, assimilation of cholesterol, enzymatic and antioxidant activity, and antifungal resistance. In addition, the effect of ultrasonic treatment was evaluated for attenuating the cultures before their possible incorporation into a food or supplement. In all of the cases, the unique commercial probiotic yeast (S. boulardii CNM I-745) was used as positive control. Results show different capabilities depending on the property studied. In general, no Saccharomyces yeasts were better in the adhesion to Caco cells, prebiotic metabolism, and presented higher variability of enzymatic activities. The ones related to cholesterol assimilation and antioxidant capability did not show a marked trend, and with respect to the attenuation process, the Saccharomyces yeasts were more resistant. For selecting the potential probiotic yeasts with better balance among all characteristics, a principal component analysis (PCA) was carried out. The most promising yeasts for use as health-promoting probiotics are Hanseniaspora osmophila 1056 and 1094, Lachancea thermotolerans 1039, and S. cerevisiae 3 and 146.

Keywords: Saccharomyces and non-Saccharomyces probiotic yeasts; functional characteristics; biotechnological potential; Caco-2/TC7 cells; prebiotic metabolisms; assimilation of cholesterol; enzymatic activity; antioxidant activity; antifungal resistance; attenuation

\section{Introduction}

Probiotics are live microorganisms with beneficial properties. Their intake in adequate amounts may confer health benefits, according to the FAO/WHO guidelines of 2002.

Most probiotics are isolated from the gut microbiota of healthy individuals or from dairy foods, which are considered a safe isolation source of microorganisms for product development. The market for biofunctional products is continuously in need of the implementation and diversification of the available products. For this purpose, a growing number of scientific studies has involved the selection of new strains with different and specific functional properties, and new microbial groups are associated with these features. Among them, Saccharomyces and non-Saccharomyces yeasts became promising probiotic candidates over the last decade. These new microorganisms are usually isolated from novel sources, such as traditional fermented foods, traditional fermented drinks, vegetables, fruit juices, fruits, and grains [1-4].

Cultures and species of Saccharomyces normally do not pose any health risk; thus, are designated as generally recognized as safe (GRAS) organisms [5,6], although some studies 
show the influence of Saccharomyces cerevisiae strains from insects on the immune system [7]. However, this genus is the most common and important microorganism associated with fermented foods throughout history. Moreover, a recent report from Li et al. [8], among others, has confirmed the GRAS status of certain non-Saccharomyces.

To evaluate the properties of putative probiotic strains, a preliminary in vitro assessment is recommended [9]. This assessment has traditionally paid special attention to the ecological origin of the strains, their tolerance to the hostile conditions of the gastrointestinal transit, and their ability to adhere to intestinal surfaces [10]. In addition, several criterial stabilities during the manufacturing processes must be taken into account [11]. Nevertheless, a deeper study of the functional and biotechnological properties is necessary for selection of new probiotic microorganisms.

Among their potential benefits, yeasts can be used to eliminate cholesterol by assimilation [3] and prevent cardiovascular diseases, considering the failure of current strategies, such as dieting and pharmacological agents [12].

They also can produce major metabolites, such as vitamins [3] and/or enzymes: esterase, protease, or lipase improve digestion by contributing to the absorption of nutrients. A deficiency of digestive enzymes can cause malnutrition, low rate of body development, allergic conditions, digestive disorders, fatigue, liver hypertrophy, or intolerance to certain foods. Another possible characteristic is the antioxidant capability against reactive oxygen species, such as superoxide $\left(\mathrm{O}_{2}{ }^{-}\right)$and hydroxyl $(\mathrm{OH})$ radicals, $\mathrm{H}_{2} \mathrm{O}_{2}$, and singlet oxygen $\left({ }^{1} \mathrm{O}_{2}\right)$, which damage cellular components by oxidizing lipids, proteins, and nucleic acids [13].

On the other hand, probiotics are tackling developing gastrointestinal symptoms, such as abdominal distension, pain, flatulence, and diarrhea, related to lactase metabolism and indigestible oligosaccharides present in pulses and legumes, such as melibiose, raffinose, and stachyose. These kinds of compounds (prebiotics [14]) promote the growth of the microorganisms present in the intestine, resulting in health benefits, such as enhanced antagonism microbiota against foreign microorganisms and contribution of the recolonization of the mucosa, after treatment with antibiotics, generation of $\mathrm{H}_{2}$ and $\mathrm{CO}_{2}$, as well as short-chain fatty acids that should inhibit the growth of pathogenic organisms.

Otherwise, and from a more practical point of view, the adhesion of the potential probiotic to epithelial cells must be studied as a previous step to the human assays. Moreover, during the inclusion in a food matrix, moderate sonication can be used to attenuate the microorganisms and consecutively introduce them into the product without risks [15-17].

Based on all of the explained - and due to the lack of information related to biotechnological characterization of potential probiotics-in the present work, twenty yeast strains isolated from different food ecosystems (winery, distillery, and fermented vegetables) whose probiotic features had previously been studied [18-20], were exhaustively characterized by study of their adhesion to Caco-2/TC7 cells, use of prebiotics and lactose, the assimilation of cholesterol, resistance to antifungals, enzymatic and antioxidant activities, and the effect of ultrasonic treatment (attenuation) on cellular viability and vitality.

\section{Materials and Methods}

\subsection{Yeast Strains}

Ten Saccharomyces cerevisiae and ten non-Saccharomyces (belonging to the genera Pichia, Lachancea, Hanseniaspora, Candida, and Zygosaccharomyces) yeast strains isolated from different food ecosystems were used (Table 1). 
Table 1. Yeast strains and their sources of isolation.

\begin{tabular}{ccc}
\hline Species & Strains & Source \\
\hline Saccharomyces boulardii & 24 & $\mathrm{CP}$ \\
\hline Saccharomyces cerevisiae & $3,6,7,95,127,128,132,137,139,146$ & $\mathrm{~W}$ \\
\hline Pichia kudriavzevii & 1003,1200 & $\mathrm{~W}$ \\
\hline Pichia membranifaciens & 1019 & $\mathrm{~W}$ \\
\hline Lachancea thermotolerans & 1039 & $\mathrm{~W}$ \\
\hline Hanseniaspora osmophila & 1056,1094 & $\mathrm{D}$ \\
\hline Candida vini & 1063 & $\mathrm{~W}$ \\
\hline Pichia anomala & 1082,1090 & $\mathrm{D}$ \\
\hline Zygosaccharomyces bailii & 1213 & $\mathrm{FV}$ \\
\hline
\end{tabular}

CP: commercial probiotic; W: winery; D: distillery; FV: fermented vegetables.

All of them were selected according to the probiotic potential in vitro shown in other works [19-21] for presenting a high resistance to the gastrointestinal tract conditions and for showing the most adequate values of the kinetic parameters. They also presented good adherence characteristics (results of autoaggregation, hydrophobicity, and biofilm formation studies), among them and with the mucosa. In addition, a commercial probiotic yeast (Saccharomyces boulardii) was used as a positive control.

For obtaining fresh cultures, each strain was grown for $24 \mathrm{~h}$ at $30^{\circ} \mathrm{C}$ in YPD (Yeast Extract Peptone Dextrose) broth (1\% yeast extract, $2 \%$ peptone and $2 \%$ dextrose) (PronadisaConda, Madrid Spain). In some experiments, it was necessary to determinate the yeasts population for carry out the inoculation with $10^{6} \mathrm{cfu} / \mathrm{mL}$. It was done using the Thoma chamber (Preciss Europe, Laboroptik Ltd., Lancing,). Once calculated, the adequate volume of broth was harvested by centrifugation at $20{ }^{\circ} \mathrm{C}(1800 \times g$ for $5 \mathrm{~min})$. Pellet was washed twice with saline solution ( $0.9 \%$, Sigma, St. Louis, MO, USA) and suspended in the corresponding medium of each assay.

Biological triplicates were performed in all experiments.

\subsection{Yeast Adhesion to Caco-2/TC7 Cells}

The mechanisms by which probiotics exert positive biological effects in the body are not yet fully understood, but adherence to the intestinal mucosa is often used to explain their mode of action [22].

Adhesion assays were performed following Diosma et al. [23] with slight modifications. Caco-2/TC7 cells, derived from a human epithelial colorectal adenocarcinoma, were routinely grown in Dulbecco's Modified Eagle Minimal Essential Medium (DMEM, Lonza, BioWhittaker ${ }^{\mathrm{TM}}$, Belgium) supplemented with $10 \%(v / v)$ fetal bovine serum (FBS), $100 \mathrm{U} / \mathrm{mL}$ penicillin-streptomycin and glutamine $(2 \mathrm{mM})$, following the procedure described by Golowczyc et al. [24]. Cells in subculture passage 23 were seeded at a concentration of $2.5 \times 10^{5}$ cells per well in 24-well tissue culture plates. Overnight cultures of yeasts were resuspended in $0.5 \mathrm{~mL}$ of Dulbecco's Modified Eagle Minimal Essential Medium (DMEM, BioWhittaker ${ }^{\mathrm{TM}}$, Belgium) with a concentration of $10^{6} \mathrm{cfu} / 0.5 \mathrm{~mL}$. Each strain suspension was added onto the monolayer culture of Caco-2/TC7 (differentiated cells).

The plates were incubated for $1 \mathrm{~h}$ at $37^{\circ} \mathrm{C}$ in a $5 \% \mathrm{CO}_{2}, 70.5 \% \mathrm{rh}$. The monolayer was then washed three times with PBS and lysed in $0.5 \mathrm{~mL}$ of sterile distilled water. To determine the number of viable yeasts associated with the Caco-2/TC7 cells, the appropriate dilutions in saline solution were plated on petrifilm YM (3M Petrifilm ${ }^{\mathrm{TM}}$, St. Paul, MN, USA) and after 2 days at room temperature, the colonies were counted. Results were expressed as the percentage of yeasts adhered to the Caco-2/TC7 cells, with respect to the population inoculated. 


\subsection{Prebiotic Metabolisms}

Certain compounds, such as fructooligosaccharides, galactooligosaccharides, and xylooligosaccharides, among others, are known to promote the development of bacteria probiotics [14]; therefore, it is of keen interest to know which nutrients are the most suitable for these strains.

\subsubsection{Aerobic Conditions}

Different prebiotic solutions were prepared with prebiotic $(10 \mathrm{~g} / \mathrm{L})$, yeast extract $(10 \mathrm{~g} / \mathrm{L})$, and peptone $(20 \mathrm{~g} / \mathrm{L})$. The prebiotics used were melibiose, raffinose, xylan, trehalose, pectin, beta-glucan, cellulose, cellobiose, and inulin (Sigma, St. Louis, MO, USA). Two controls were used: the yeast control (yeast with yeast extract and peptone) and medium control (prebiotic, yeast extract, and peptone).

In parallel, and to deplete the residual sugar, the overnight cultures were incubated for $6 \mathrm{~h}$ at $30{ }^{\circ} \mathrm{C}$ in saline solution $(0.9 \%)$. Then, they were inoculated, at a concentration of $10^{6} \mathrm{cfu} / \mathrm{mL}$, into $190 \mu \mathrm{L}$ of prebiotic solution using 24-well plates and incubated at $30^{\circ} \mathrm{C}$.

The assimilation verification was performed through readings on a microplate spectrophotometer (ELx808 ${ }^{\mathrm{TM}}$ Absorbance Microscope Reader), with measurements at $600 \mathrm{~nm}$ for 5 days. It was assumed that a strain had used the prebiotic when there was an absorbance increment of at least 0.55 with respect to the yeast control.

\subsubsection{Anaerobic Conditions}

The same protocol detailed in Section 2.3.1 was used, but the plates with the prebiotic solutions (once inoculated) were sealed with Vaseline.

\subsection{Assimilation of Cholesterol}

Some of the beneficial effects of probiotics in the clinical field may be their ability to assimilate cholesterol, as an alternative to the prevention of cardiovascular diseases [25].

YPD growth medium was used, supplemented with bile salts (5\%, Oxoid, Basingstoke, UK) and cholesterol ( $0.2 \%$, Sigma-Aldrich Co., St. Louis, MO, USA). Then it was inoculated with $10^{6} \mathrm{cfu} / \mathrm{mL}$ of each strain for $48 \mathrm{~h}$ at $30^{\circ} \mathrm{C}$. Cholesterol was measured using the process described by Gilliland et al. [26]. To determine the assimilated cholesterol in the medium, the absorbance was read at $600 \mathrm{~nm}$ (Jasco V-530 spectrophotometer, Madrid, Spain) at $0 \mathrm{~h}$ and $48 \mathrm{~h}$. Percentage assimilation was calculated as follows:

$$
\left(1-\left(\frac{\mathrm{A} 48 \mathrm{~h}}{\mathrm{~A} 0 \mathrm{~h}}\right)\right) \times 100 \%
$$

\subsection{Enzymatic Activity}

Another benefit of probiotics could be their contribution to digestion, providing different enzymes that facilitate the degradation of macronutrients, improving the assimilation of nutrients.

The study of certain enzymatic activities (alkaline phosphatase, esterase (C 4), esterase lipase (C 14), lipase, leucine arylamidase, valine arylamidase, cystine arylamidase, trypsin, $\alpha$-chymotrypsin, acid phosphatase, and naphthol-AS-BI-phosphohydrolase) was carried out with a semi-quantitative standardized API ZYM micro method (BioMérieux, Madrid, Spain).

Every microwell was inoculated with $65 \mu \mathrm{L}$ of a suspension of $10^{6} \mathrm{cfu} / \mathrm{mL}$. It was incubated for $4 \mathrm{~h}$ at $37^{\circ} \mathrm{C}$. After this time, the reagents ZYM A (tri-hydroxy-methyl-aminomethane, $\mathrm{HCl}$, and lauryl sulfate) and ZYM B (fast blue BB and 2-methoxy-ethanol) were added, and the results were taken 15 min later.

In addition, lactase activity was also evaluated, both in aerobic and anaerobic conditions. The methodology used was the one described in Sections 2.3.1 and 2.3.2 respectively, using lactose as a carbon source (Sigma Chemical, St. Louis, MO, USA). 


\subsection{Antioxidant Activity}

Other metabolic functions of probiotics are based on secreting functional bioactive molecules to protect the human body, for example, against free radicals [13].

Two assays were carried out to study the antioxidant activity: free radical scavenging and catalase activity.

Free radical scavenging was assessed through a colorimetric DPPH (1,1-diphenyl-2picrylhydrazyl) test, according to the method described by Brand-Williams et al. [27], with some modifications.

In short, aliquots of $0.4 \mathrm{~mL}$ of yeast cell suspensions (with a population of $10^{6} \mathrm{cfu} / \mathrm{mL}$ ) were mixed with $1.6 \mathrm{~mL}$ of DPPH $6 \times 10^{-5} \mathrm{M}$ methanolic solution [28]. The mixture was shaken vigorously and then incubated at $30{ }^{\circ} \mathrm{C}$ for $30 \mathrm{~min}$ in the dark. Absorbance at $517 \mathrm{~nm}$ was measured (Jasco V-530 spectrophotometer, Madrid, Spain) at "time 0" (A0) and after incubation (AF). The scavenging free radical percentage was calculated as follows:

$$
\left(1-\left(\frac{\mathrm{AF}}{\mathrm{A} 0}\right)\right) \times 100 \%
$$

The results were expressed as free radical scavenging percentages.

The second assay, catalase activity, was done by adding $3 \%$ hydrogen peroxide $(v / v)$ to $300 \mu \mathrm{L}$ of a $10^{6} \mathrm{cfu} / \mathrm{mL}$ suspension of each yeast strain, according to the Whittenbury [29] method. The presence of bubbles indicated positive catalase activity.

\subsection{Antifungal Resistance}

Knowing the behavior of yeasts used as probiotics against antifungals opens the possibility of their use during treatments with these drugs.

Resistance to certain common antifungals was evaluated. The methodology used was as follows. Each yeast strain was seeded on YPD agar Petri dishes using the microbial turf technique, and then a drop of $5 \mu \mathrm{L}$ of each antifungal solution was added. The plates were incubated at $30^{\circ} \mathrm{C}$ for $48 \mathrm{~h}$. The sensitivity of the strains against the antifungal compounds was determined by measuring the diameter $(\mathrm{cm})$ of total (complete absence of $w$ growth) and partial (slight growth) inhibition zones.

The antifungals used were nystatin $(21 \mathrm{mg} / \mathrm{mL})\left(\right.$ Mycostatin ${ }^{\circledR}$, Bristol-Myers Squibb, S.A.), ciclopirox olamine $(1 \mathrm{mg} / \mathrm{mL})\left(\right.$ CycloChem ${ }^{\circledR}$, Ferrer $)$, clotrimazole $(10 \mathrm{mg} / \mathrm{mL})$ (Canesten ${ }^{\circledR}$, Bayer), and fluconazole $(150 \mathrm{mg} / \mathrm{mL})$ (Fluconazol ${ }^{\circledR}$, Cinfa). All of them were purchased in a local pharmacy (Ciudad Real, Spain).

\subsection{Attenuation}

Moderate sonication can be used to attenuate the microorganisms and consecutively introduce them into a food matrix [15].

\subsubsection{Setup of Method}

The best protocol would be one that makes microorganisms lose their vitality, but not viability. The conditions tested were a combination of the population $\left(10^{6}\right.$ and $\left.10^{7} \mathrm{cfu} / \mathrm{mL}\right)$, the amplitude $(60 \%$ and $80 \%)$, the time in the sonication process $(1,2$, and $3 \mathrm{~min})$, and pulses (absence and presence of pulses, $2 \mathrm{~s}$ on and $10 \mathrm{~s}$ off) (Q700, Qsonica Sonicators, Newtown, CT, USA). Before each treatment, the sonicator probe was washed with sterile distilled water, and immediately after processing, samples were cooled in ice. Loss of viability was evaluated by seeding on a plate.

\subsubsection{Attenuation Effects}

One experiment with six yeasts (two Saccharomyces strains ( 3 and 24) and four nonSaccharomyces strains $(1003,1019,1082$, and 1090)) was carried out to check whether attenuation affected vitality as well as viability. The effect was measured after sonication and kinetic results were compared with the ones obtained from the culture with the same population without sonication. 
Viability was obtained by account in YPD agar and vitality was quantified by means of impedance values (Microtrac 4200, SY-LAB instruments, Neupurkersdorf, Austria). Every $2 \mathrm{~min}$, the MicroTrac measures the variation of impedance of the $\mathrm{KOH}$ solution at $0.2 \%$, which takes the generated $\mathrm{CO}_{2}$ from the YPD broth inoculated with the strain under study.

Negative and positive controls (samples without yeast and samples with non-sonicated yeasts, respectively) were carried out.

\subsection{Statistical Analysis}

The results were analyzed through different statistical analyses. To determine significant differences between the strains, a one-way analysis of variance (ANOVA) was carried out on every experiment, along with Student's $t$-test or Duncan test $(p<0.05)$. After all of the experiments, a principal component analysis (PCA) was performed on the correlation matrix and used as a selection method. The software programs used were Excel 2013 (Microsoft Corporation) and SPSS (IBM SPSS Statistics v20).

\section{Results and Discussion}

\subsection{Yeast Adhesion to Caco-2/TC7 Cells}

The adhesive capacity of selected yeasts was examined in vitro with the Caco-2/TC7 intestine-derived cell line. A clear difference between the behavior of Saccharomyces and non-Saccharomyces strains was observed: the latter had a higher capacity for adhesion.

Percentages of adhesion (Figure 1) showed values of between $26.78 \%$ (S. boulardii) and $78.38 \%$ (L. thermotolerans). According to the Duncan test $(\alpha=0.05, \mathrm{~F}=116.39, p=0.00)$, there were eight significantly different, sorted by decreasing percentage of adhesion. The highest results were for one Saccharomyces and two non-Saccharomyces strains $(3,1039$, and 1063 ) with values of $76.37 \pm 2.10 \%, 78.30 \pm 0.49 \%$, and $75.52 \pm 2.96 \%$, respectively. The next three higher groups include the rest of the non-Saccharomyces, except for strain 1003 (P. kudriavzevii).
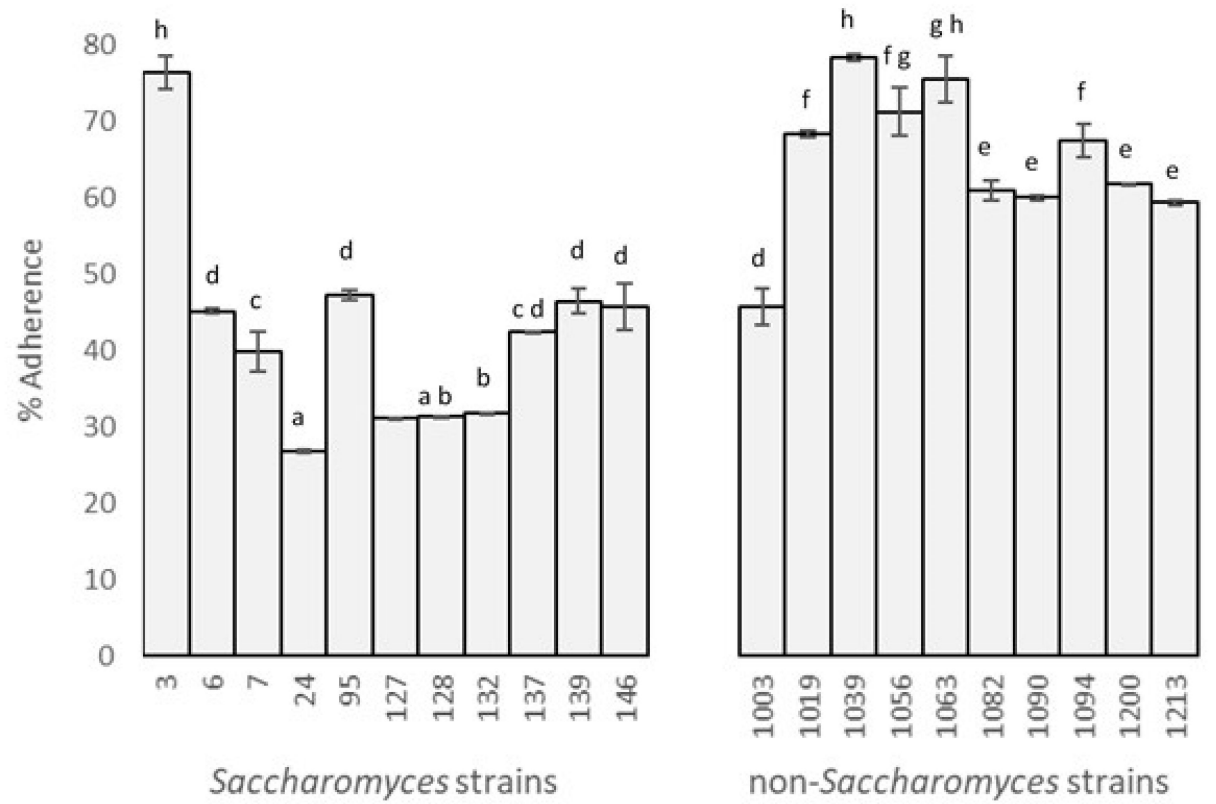

Figure 1. Percentages of yeast adhesion to Caco-2/TC7 cells (different letters indicate significant differences between strains).

All Saccharomyces, except for strain 3, were included in the groups with lowest values. Surprisingly, the commercial probiotic, used as a positive control, presented a low percentage of adhesion. 
A high correlation has been found between adhesion capacity and biofilm formation after the gastrointestinal tract (a capacity that has been examined for the same yeasts in previous studies $[19,20])$. This could translate to successful adhesion to the mucosa in humans.

Consistent with these results, Diosma et al. [23] reported 60\% adhesion for nonSaccharomyces and less than 30\% for Saccharomyces strains, and Kumura et al. [30] found $80 \%$ adhesion for Kluyveromyces marxianus. On the other hand, the results presented by Golowczyc et al. [24] for eight Lactobacillus sp. strains isolated from kefir grains were worse than the ones presented here.

Regarding the growth on the epithelial cells, the morphology was unicellular in all cases and no hyphae were observed. This is key for the aspect in the safety of probiotic microorganisms (Figure 2) [9].

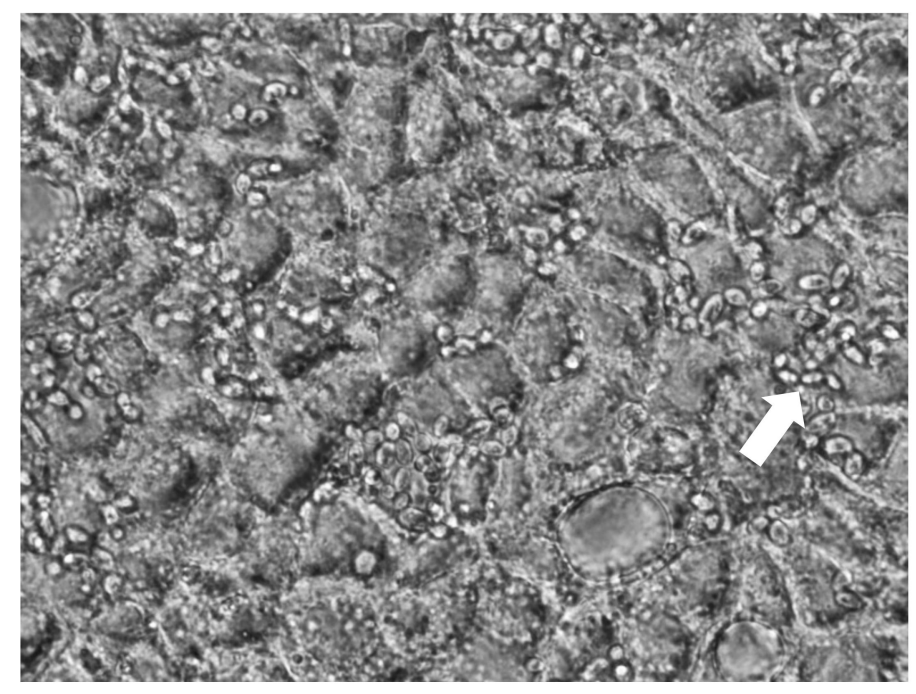

Figure 2. Adhesion of yeast strain 3 to Caco-2/TC7 cells. White arrow points to yeast cells.

\subsection{Prebiotics Metabolism}

\subsubsection{Aerobic Conditions}

The results of assimilation for the nine prebiotics studied showed that the capability of non-Saccharomyces yeasts was higher than that observed in Saccharomyces. In most cases, the prebiotics were absorbed within $24 \mathrm{~h}$ (Table 2).

The most assimilated prebiotics were raffinose and pectin, followed by cellobiose and trehalose. All strains were able to use the raffinose within $24 \mathrm{~h}$, although according to Kurtzman et al. [31], Saccharomyces should be the only one capable of using it. In addition, other prebiotics were assimilated, such as inulin, melibiose, xylan, and cellobiose. The National Collection of Yeast Cultures (NYCN) (Norwich, UK) contains several S. cerevisiae strains that also use trehalose and raffinose in aerobic conditions from bakeries, kefir, or distilleries.

Out of the non-Saccharomyces strains, only H. osmophila (1094) was able to assimilate all prebiotics within $24 \mathrm{~h}$; it achieved a high absorbance increment in the assimilation of cellulose, inulin, melibiose, xylan, trehalose, cellobiose, and beta-glucans (in comparison with the rest of the strains studied). The other H. osmophila strain (1056) showed assimilation of only raffinose and beta-glucans, in both cases within $24 \mathrm{~h}$. Two H. osmophila strains from NCY showed the ability to assimilate cellobiose obtained from ripe grapes and soil. Excellent results were also shown by some strains of the Pichia genus: strains 1003 and 1090 were able to assimilate seven prebiotics in the first $24 \mathrm{~h}$, and strain 1082 and C. vini (1063) assimilated six prebiotics within $24 \mathrm{~h}$. 
Table 2. Prebiotic metabolisms under aerobic and anaerobic conditions. Increase in absorbance at $600 \mathrm{~nm}$ between 0 and $>72 \mathrm{~h}$.

\begin{tabular}{|c|c|c|c|c|c|c|c|c|c|c|}
\hline & \multirow{3}{*}{ STRAINS } & \multicolumn{9}{|c|}{ Prebiotic/Assimilation Time } \\
\hline & & \multicolumn{9}{|c|}{ Aerobic Conditions } \\
\hline & & Cellulose & Inulin & Melibiose & Raffinose & Xylan & Trehalose & Pectin & Cellobiose & Beta-Glucans \\
\hline \multirow{11}{*}{ 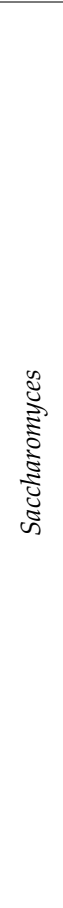 } & 3 & - & - & - & $\begin{array}{c}0.56 \\
(0-24]\end{array}$ & - & - & $\begin{array}{c}0.50 \\
(48-2]\end{array}$ & - & - \\
\hline & 24 & - & - & - & $\begin{array}{c}0.83 \\
(0-24]\end{array}$ & - & - & $\begin{array}{c}0.53 \\
(48-72]\end{array}$ & $\begin{array}{c}0.51 \\
(48-72]\end{array}$ & - \\
\hline & 6 & - & - & - & $\begin{array}{c}0.93 \\
(0-24]\end{array}$ & - & $0.53>72$ & $\begin{array}{c}0.55 \\
(24-48]\end{array}$ & $\begin{array}{c}0.50 \\
(24-48]\end{array}$ & $0.54(24-48]$ \\
\hline & 7 & - & - & - & $\begin{array}{c}0.81 \\
(0-24]\end{array}$ & - & $0.51>72$ & $0.58>72$ & - & - \\
\hline & 95 & - & - & - & $\begin{array}{c}0.84 \\
(0-24]\end{array}$ & - & - & $0.53>72$ & - & - \\
\hline & 127 & - & - & $\begin{array}{c}0.61 \\
(24-48]\end{array}$ & $\begin{array}{c}0.92 \\
(0-24]\end{array}$ & $\begin{array}{c}0.52 \\
(48-72]\end{array}$ & $0.72>72$ & $\begin{array}{c}0.52 \\
(48-72]\end{array}$ & $\begin{array}{c}0.51 \\
(48-72]\end{array}$ & - \\
\hline & 128 & - & - & $\begin{array}{c}0.52 \\
(24-48]\end{array}$ & $\begin{array}{c}0.99 \\
(0-24]\end{array}$ & - & $0.58>72$ & $\begin{array}{c}0.53 \\
(24-48]\end{array}$ & $\begin{array}{c}0.61 \\
(48-72]\end{array}$ & - \\
\hline & 132 & - & - & - & $\begin{array}{c}0.59 \\
(0-24]\end{array}$ & - & - & $\begin{array}{c}0.55 \\
(48-72]\end{array}$ & - & - \\
\hline & 137 & - & $0.52>72$ & $0.56>72$ & $\begin{array}{c}0.73 \\
(0-24]\end{array}$ & - & $0.55>72$ & $0.52>72$ & - & - \\
\hline & 139 & - & $\begin{array}{c}0.61 \\
(48-72]\end{array}$ & $0.52>72$ & $\begin{array}{c}0.97 \\
(0-24]\end{array}$ & - & $\begin{array}{c}0.67 \\
(0-24]\end{array}$ & $\begin{array}{c}0, .52 \\
(48-72]\end{array}$ & $0.70>72$ & - \\
\hline & 146 & - & - & $0.50>72$ & $\begin{array}{c}1.16 \\
(0-24]\end{array}$ & - & - & $0.50>72$ & $0.60>72$ & - \\
\hline \multirow{10}{*}{ 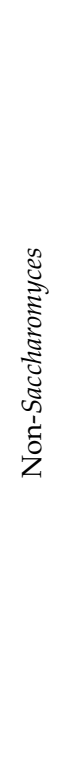 } & 1003 & - & - & $\begin{array}{c}0.69 \\
(0-24]\end{array}$ & $\begin{array}{c}0.72 \\
(0-24]\end{array}$ & $\begin{array}{c}0.58 \\
(0-24]\end{array}$ & $\begin{array}{c}0.74 \\
(0-24]\end{array}$ & $\begin{array}{c}0.89 \\
(0-24]\end{array}$ & $\begin{array}{c}0.59 \\
(0-24]\end{array}$ & $1.14(0-24]$ \\
\hline & 1019 & - & - & - & $\begin{array}{c}0.69 \\
(0-24]\end{array}$ & - & - & - & - & - \\
\hline & 1039 & - & - & $\begin{array}{c}0.75 \\
(24-48]\end{array}$ & $\begin{array}{c}0.86 \\
(0-24]\end{array}$ & $\begin{array}{c}0.72 \\
(24-48]\end{array}$ & $\begin{array}{c}0.70 \\
(24-48]\end{array}$ & $0.74>72$ & $\begin{array}{c}0.54 \\
(48-72]\end{array}$ & $0.58(48-72]$ \\
\hline & 1056 & - & - & - & $\begin{array}{c}0.56 \\
(0-24]\end{array}$ & - & - & - & - & $0.76(0-24]$ \\
\hline & 1063 & - & - & - & $\begin{array}{c}0.53 \\
(0-24]\end{array}$ & $\begin{array}{c}0.56 \\
(0-24]\end{array}$ & $\begin{array}{c}0.54 \\
(0-24]\end{array}$ & $\begin{array}{c}0.55 \\
(0-24]\end{array}$ & $\begin{array}{c}0.86 \\
(0-24]\end{array}$ & $0.95(0-24]$ \\
\hline & 1082 & - & $\begin{array}{c}0.56 \\
(0-24]\end{array}$ & - & $\begin{array}{c}0.53 \\
(0-24]\end{array}$ & $\begin{array}{c}0.55 \\
(0-24]\end{array}$ & - & $\begin{array}{c}0.80 \\
(0-24]\end{array}$ & $\begin{array}{c}0.89 \\
(0-24]\end{array}$ & $0.89(0-24]$ \\
\hline & 1090 & - & $\begin{array}{c}0.88 \\
(0-24]\end{array}$ & $\begin{array}{c}0.66 \\
(0-24]\end{array}$ & - & $\begin{array}{c}0.55 \\
(0-24]\end{array}$ & $\begin{array}{c}0.63 \\
(0-24]\end{array}$ & $\begin{array}{c}0.96 \\
(0-24]\end{array}$ & $\begin{array}{c}1.08 \\
(0-24]\end{array}$ & $1.12(0-24]$ \\
\hline & 1094 & $\begin{array}{c}0.6 \\
(0-24]\end{array}$ & $\begin{array}{c}0.73 \\
(0-24]\end{array}$ & $\begin{array}{c}0.94 \\
(0-24]\end{array}$ & $\begin{array}{c}0.86 \\
(0-24]\end{array}$ & $\begin{array}{c}0.77 \\
(0-24]\end{array}$ & $\begin{array}{c}1.56 \\
(0-24]\end{array}$ & $\begin{array}{c}0.94 \\
(0-24]\end{array}$ & $\begin{array}{c}1.60 \\
(0-24]\end{array}$ & $1.27(0-24]$ \\
\hline & 1200 & - & $0.61>72$ & - & - & - & $\begin{array}{c}0.50 \\
(0-24]\end{array}$ & $\begin{array}{c}0.82 \\
(0-24]\end{array}$ & $0, .2(0-24]$ & $1.06(0-24]$ \\
\hline & 1213 & - & - & - & - & - & - & - & - & $0.52(24-48]$ \\
\hline
\end{tabular}


Table 2. Cont.

\begin{tabular}{|c|c|c|c|c|c|c|c|c|c|c|}
\hline & \multirow{3}{*}{ STRAINS } & \multicolumn{9}{|c|}{ Prebiotic/Assimilation Time } \\
\hline & & \multicolumn{9}{|c|}{ Aerobic Conditions } \\
\hline & & Cellulose & Inulin & Melibiose & Raffinose & Xylan & Trehalose & Pectin & Cellobiose & Beta-Glucans \\
\hline & & \multicolumn{9}{|c|}{ Anaerobic Conditions } \\
\hline & & Cellulose & Melibiose & Raffinose & Xylan & Trehalose & Cellobiose & $\begin{array}{l}\text { Beta- } \\
\text { Glucans }\end{array}$ & & \\
\hline \multirow{11}{*}{ 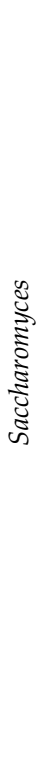 } & 3 & - & - & - & - & - & - & - & & \\
\hline & 24 & - & - & - & - & $0.56>72$ & $\begin{array}{c}0.57 \\
(24-48]\end{array}$ & - & & \\
\hline & 6 & - & - & - & - & - & - & - & & \\
\hline & 7 & - & - & - & - & $0.50>72$ & - & - & & \\
\hline & 95 & - & - & - & - & $\begin{array}{c}0.53 \\
(48-72]\end{array}$ & - & - & & \\
\hline & 127 & - & - & - & - & $0.58>72$ & $\begin{array}{c}0.57 \\
(48-72]\end{array}$ & - & & \\
\hline & 128 & - & - & - & - & $0.72>72$ & $0.58>72$ & - & & \\
\hline & 132 & - & - & $0.53>72$ & - & $\begin{array}{c}0.55 \\
(48-72]\end{array}$ & - & - & & \\
\hline & 137 & - & - & - & - & $\begin{array}{c}0.56 \\
(48-72]\end{array}$ & - & - & & \\
\hline & 139 & - & - & $0.56>72$ & - & $\begin{array}{c}0.56 \\
(48-72]\end{array}$ & $\begin{array}{c}0.55 \\
(0-24]\end{array}$ & - & & \\
\hline & 146 & - & - & - & - & $0.70>72$ & $\begin{array}{c}0.58 \\
(0-24]\end{array}$ & - & & \\
\hline \multirow{10}{*}{ 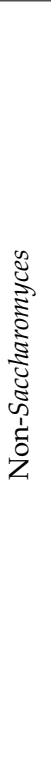 } & 1003 & - & - & - & - & - & $\begin{array}{c}0.50 \\
(24-48]\end{array}$ & - & & \\
\hline & 1019 & - & - & - & $\begin{array}{c}0.72 \\
(24-48]\end{array}$ & - & - & - & & \\
\hline & 1039 & $\begin{array}{c}0.50 \\
(0-24]\end{array}$ & - & - & - & - & $\begin{array}{c}0.51 \\
(24-48]\end{array}$ & $\begin{array}{c}0.68 \\
(24-48]\end{array}$ & & \\
\hline & 1056 & $\begin{array}{c}0.57 \\
(24-48]\end{array}$ & - & $\begin{array}{c}0.91 \\
(0-24]\end{array}$ & $\begin{array}{c}0.76 \\
(48-72]\end{array}$ & $\begin{array}{c}0.74 \\
(24-48]\end{array}$ & - & - & & \\
\hline & 1063 & - & - & - & $\begin{array}{c}0.64 \\
(24-48]\end{array}$ & - & $\begin{array}{c}0.54 \\
(24-48]\end{array}$ & $\begin{array}{c}0.64 \\
(24-48]\end{array}$ & & \\
\hline & 1082 & - & - & $\begin{array}{c}0.51 \\
(24-48]\end{array}$ & $\begin{array}{c}0.56 \\
(0-24]\end{array}$ & - & - & - & & \\
\hline & 1090 & - & - & - & $\begin{array}{c}0.58 \\
(48-72]\end{array}$ & - & - & - & & \\
\hline & 1094 & - & - & - & - & - & $\begin{array}{c}0.58 \\
(0-24]\end{array}$ & - & & \\
\hline & 1200 & - & - & - & - & $0.54>72$ & - & - & & \\
\hline & 1213 & - & $\begin{array}{c}0,65 \\
(48-72]\end{array}$ & - & $\begin{array}{c}0.50 \\
(24-48]\end{array}$ & - & - & - & & \\
\hline
\end{tabular}

Prebiotics that were not used by any strain have been omitted. "-" Means prebiotic was not used.

\subsubsection{Anaerobic Conditions}

In contrast with aerobic conditions, only seven prebiotics were fermented under anaerobic conditions (Table 2). In general, yeasts need longer periods to use prebiotics as a carbon source in anaerobic conditions. The most fermented prebiotic was trehalose and the strain capable of fermenting most compounds was H. osmophila (1056), followed by L. thermotolerans (1039) and C. vini (1063), which fermented three prebiotics within $48 \mathrm{~h}$. Other non-Saccharomyces that yielded good results were P. kudriavzevii, H. osmophila, and 
Z. bailii, which fermented cellobiose, trehalose, raffinose, xylan, and melibiose, although these activities had not been reported by Kurtzman et al. [31].

Unlike under aerobiosis conditions, only two strains of $S$. cerevisiae were able to ferment raffinose while nine of the eleven strains were able to ferment trehalose and five of them the cellobiose, although, according to Kurtzman et al. [31], S. cerevisiae only reported to ferment raffinose, as in the NCYC catalogue.

\subsection{Assimilation of Cholesterol}

The highest percentages of assimilation were from five strains of Saccharomyces (3, 24, 95,132 , and 146), with the commercial probiotic being one of them, although this ability was not discriminant between the strains $(\alpha=0.05, \mathrm{~F}=2.87, p=0.10)$. All of them were able to remove between $78.52 \pm 1.8 \%$ and $88.92 \pm 2.4 \%$ of cholesterol from YPD broth. These assimilation values were similar to the data obtained by Psomas et al. [32] for some Saccharomyces sp. strains and higher than those obtained by Chen et al. [33] (between $0 \%$ and $45.70 \pm 2.6 \%$ for non-Saccharomyces strains isolated from raw milk).

\subsection{Enzymatic Activity}

In the present study, specific digestive enzyme activities were assessed. The results are shown in Table 3. The majority of the Saccharomyces strains presented the same enzymatic profile (esterase C4, esterase C8 lipase, leucine arylamidase, acid phosphatase, and phosphohydrolase). Regarding the non-Saccharomyces strains, they presented a higher variability, presenting different activities (esterase (C4), esterase lipase (C8), leucine arylamidase, valine arylamidase, cystine arylamidase, acid phosphatase, and phosphohydrolase). A similar enzymatic profile was found by Psomas [34] in strains of S. cerevisiae, and in non-Saccharomyces isolates from infant feces and from feta cheese with some probiotic properties, where all strains exhibited acid phosphatase activity, esterase and esteraselipase activity and none of the strains presented trypsin or $\alpha$-chymotrypsin activity. In addition, other studies [35] with selected probiotics of lactobacilli derived from chicken feces found similar results for leucine, arylamidase, cystine, arylamidase, acid phosphatase, and naphthol-AS-BI-phosphohydrolase activities. Therefore, a priori, these activities give them an adequate profile as probiotic strains. They can enhance enzyme activities since can maintain the gut homeostasis [36].

Regarding lactose activity, none of the strains was able to assimilate or ferment lactose.

Table 3. Qualitative analysis of the enzymatic activity shown by the yeasts.

\begin{tabular}{|c|c|c|c|c|c|c|c|c|c|c|c|c|}
\hline & \multirow{2}{*}{ Strain } & \multicolumn{11}{|c|}{ Enzyme Studied * } \\
\hline & & 02 & 03 & 04 & 05 & 06 & 07 & 08 & 09 & 10 & 11 & 12 \\
\hline \multirow{11}{*}{ 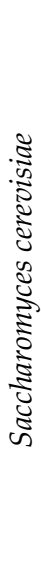 } & 3 & - & + & + & - & + & + & + & - & - & + & + \\
\hline & 6 & - & - & - & - & + & - & - & - & - & - & + \\
\hline & 7 & - & + & + & - & + & - & - & - & - & + & + \\
\hline & 24 & - & + & + & - & + & - & - & - & - & + & + \\
\hline & 95 & - & + & + & - & + & - & - & - & - & - & + \\
\hline & 127 & - & + & + & - & + & - & - & - & - & + & + \\
\hline & 128 & - & + & + & - & + & - & - & - & - & + & + \\
\hline & 132 & - & - & - & - & + & - & - & - & - & + & + \\
\hline & 137 & - & + & - & - & + & - & - & - & - & + & + \\
\hline & 139 & - & + & + & - & + & - & - & - & - & + & + \\
\hline & 146 & - & - & - & - & + & - & - & - & - & + & + \\
\hline
\end{tabular}


Table 3. Cont.

\begin{tabular}{|c|c|c|c|c|c|c|c|c|c|c|c|c|}
\hline & \multirow{2}{*}{ Strain } & \multicolumn{11}{|c|}{ Enzyme Studied * } \\
\hline & & 02 & 03 & 04 & 05 & 06 & 07 & 08 & 09 & 10 & 11 & 12 \\
\hline \multirow{9}{*}{ 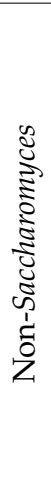 } & 1003 & - & + & + & - & + & - & - & - & - & + & + \\
\hline & 1019 & + & + & + & - & + & - & - & - & - & + & + \\
\hline & 1039 & - & - & - & - & + & - & - & - & - & - & + \\
\hline & 1056 & - & - & - & - & + & - & - & - & - & + & + \\
\hline & 1063 & - & + & + & + & + & - & - & - & - & + & + \\
\hline & 1082 & - & + & - & - & + & - & - & - & - & + & + \\
\hline & 1090 & - & + & + & - & + & - & - & - & - & + & + \\
\hline & 1094 & - & + & + & - & + & - & - & - & - & + & + \\
\hline & 1200 & - & + & + & - & + & - & - & - & - & - & + \\
\hline
\end{tabular}

*02: Alkaline phosphatase; 03: esterase (C 4); 04: esterase lipase (C 14); 05: lipase; 06: leucine arylamidase; 07: valine arylamidase; 08: cystine arylamidase; 09: trypsin; 10: $\alpha$-chymotrypsin; 11: acid phosphatase; 12 : naphthol-ASBI-phosphohydrolase. Positive activity: "+"; activity not detected: " - ".

\subsection{Antioxidant Activity}

All of the yeasts exhibited antioxidative activity through scavenging free radical from the medium. The values obtained were between $12.08 \%$ and $33.71 \%$ inhibition, and two significantly different groups were found $(\alpha=0.05, \mathrm{~F}=5.62$, Significance $=0.00)$. The second group, which presents the best properties, includes all of the strains except some non-Saccharomyces $(1019,1039,1056$, and 1213), which are in the first group. The strains with the highest percentage of reduction of DPPH were two Saccharomyces strains ( 3 and 6) and one P. kudriavzevii (1200) with values of $33.71 \%, 32.66 \%$, and $33.42 \%$, respectively. Trotta et al. [27] and de Lima et al. [37] also found percentages of antioxidant activity in the same range for S. cerevisiae, S. boulardii, and Debaryomyces hansenii.

In addition, all strains were positive for catalase; that is, these yeasts have an enzyme defense system capable of transforming the reactive oxygen species of hydrogen peroxide into $\mathrm{O}_{2}$ and $\mathrm{H}_{2} \mathrm{O}[38,39]$. This activity could be effective in alleviating inflammation in an inflammatory bowel disease, as reported by Tomusiak-Plebanek et al. [40].

\subsection{Antifungal Resistance}

All of the strains showed a degree of inhibition against the antifungals used, except for 1056 (H. osmophila), which, when in contact with ciclopirox olamine, did not show any halo of inhibition, and is therefore totally resistant to this antifungal.

Figure 3 shows clear examples of total and partial inhibition. In the case of nystatin and ciclopirox olamine, the strains with the highest resistance (and therefore the smallest halo of inhibition) were non-Saccharomyces. On the other hand, with clotrimazole and fluconazole, Saccharomyces strains were the most resistant. All data are shown in Figure 4a,b.

The yeasts studied could continue to exert their beneficial effect on the organism without being affected by the consumption of antibiotics or even certain antifungal drugs (especially strains 3, 1056, and 1094). 


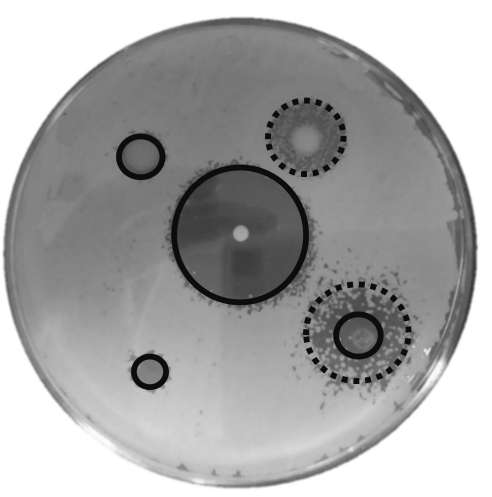

Figure 3. Inhibition halo of yeast growth in presence of antifungals assayed. Black line/circle represents total inhibition of the yeast growth, and dotted line/circle represents partial inhibition of the yeast growth.

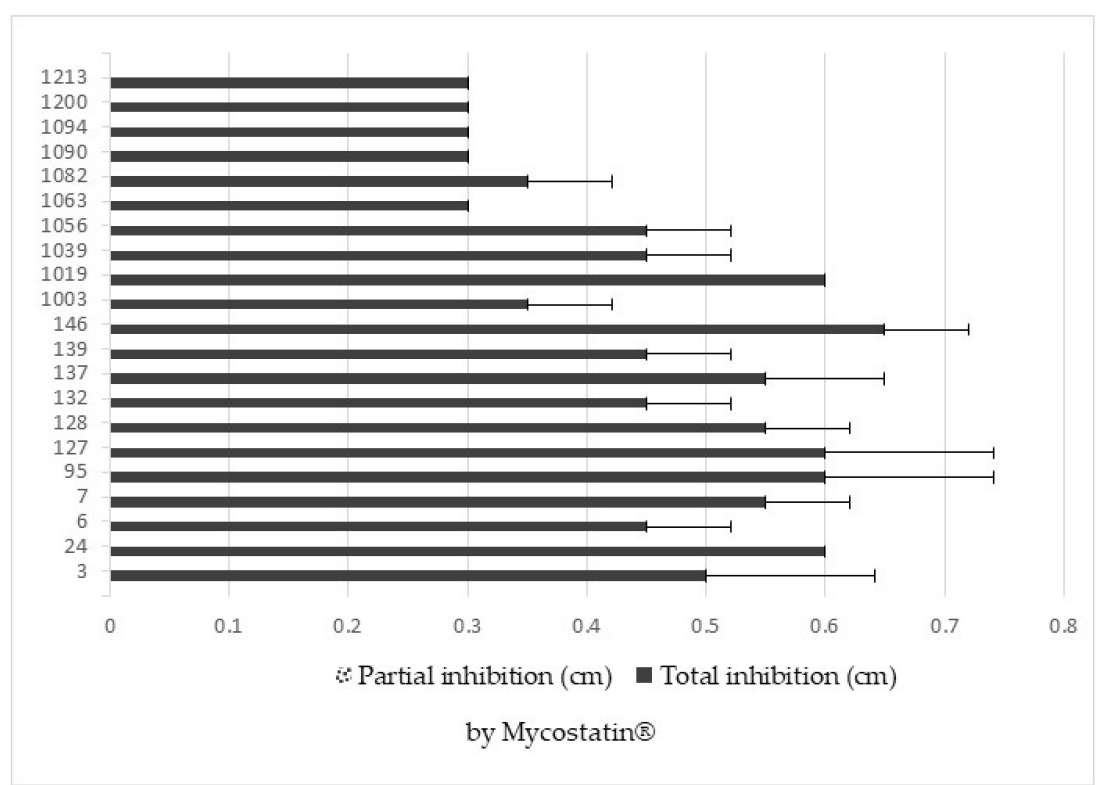

(a)

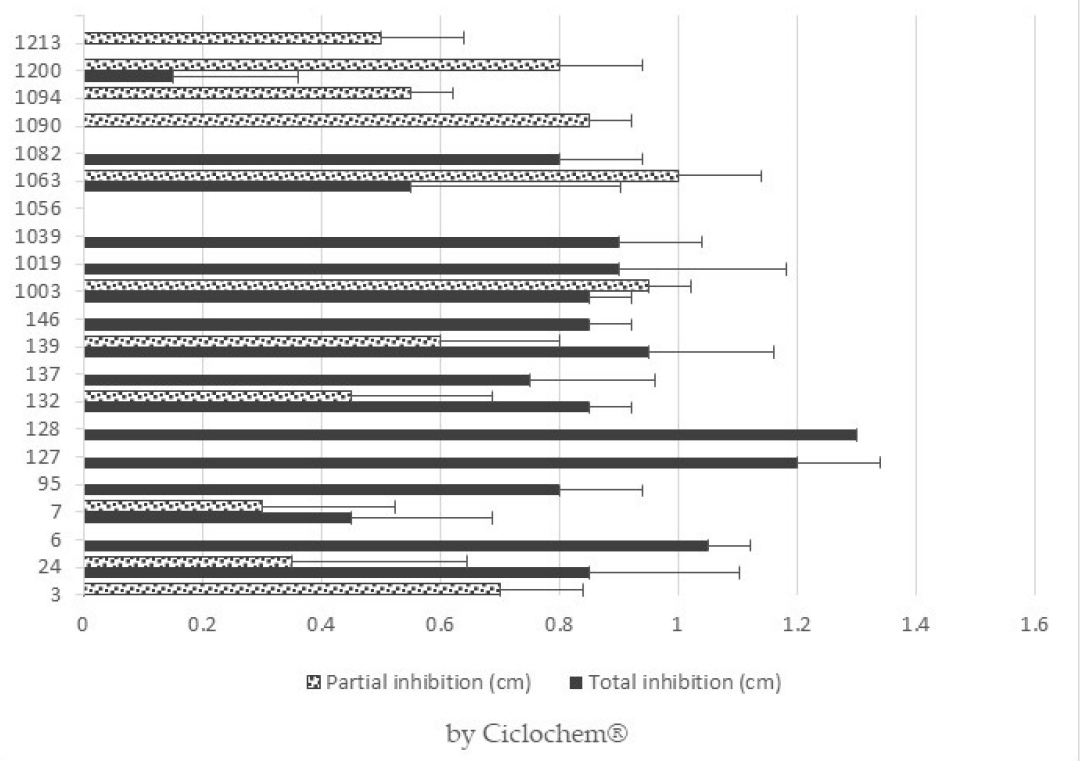

(b)

Figure 4. Cont. 


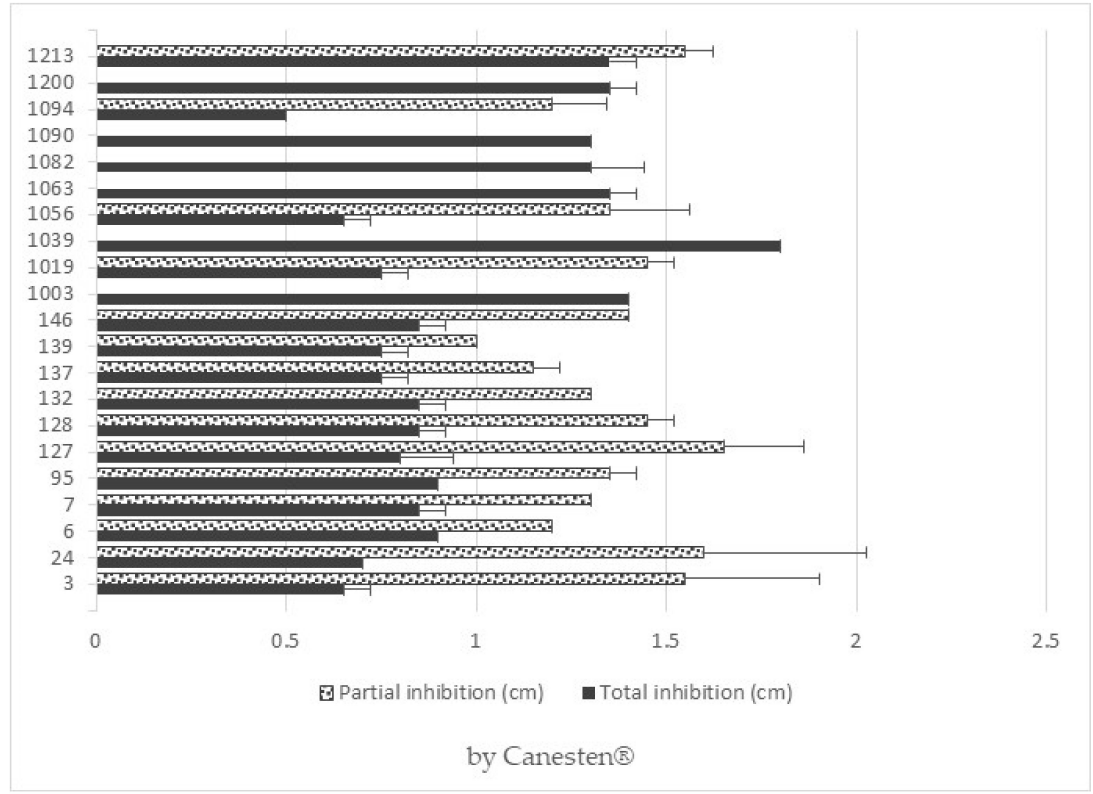

(c)

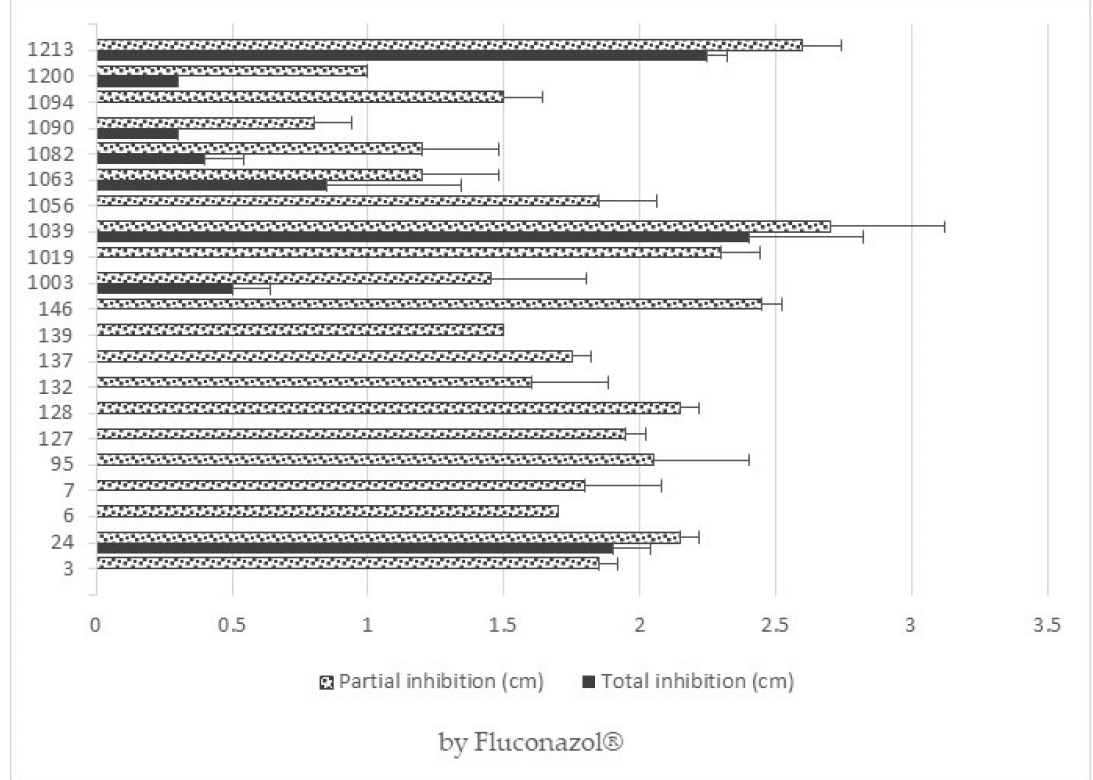

(d)

Figure 4. Partial and total inhibition of each yeast against $\operatorname{Mycostatin}{ }^{\circledR}(\mathbf{a}), \operatorname{Ciclochem}^{\circledR}(\mathbf{b})$, Canesten $^{\circledR}(\mathbf{c})$, and Fluconazol ${ }^{\circledR}(\mathbf{d})$.

\subsection{Attenuation}

\subsubsection{Setup of the Method}

This was done to find the most suitable parameters, taking into account the compromise between maintaining viability and the loss of vitality. The sonication time was the factor that most affected the yeasts' viability after the sonication process (Table 4). The attenuation conditions chosen were $60 \%$ amplitude and a total time of 2 min (with pulses of $2 \mathrm{~s}$ on and $10 \mathrm{~s}$ off), since the loss of viability produced was not significant. 
Table 4. Viability loss percentage for different proven conditions in the attenuation setup.

\begin{tabular}{cccccc}
\hline \multirow{2}{*}{$\begin{array}{c}\text { Amplitude } \\
(\mathbf{\%})\end{array}$} & $\begin{array}{c}\text { Total Time } \\
(\mathbf{m i n})\end{array}$ & \multicolumn{2}{c}{ Pulses (s) } & $\begin{array}{c}\text { Initial Population } \\
\mathbf{1 0} \mathbf{7} \mathbf{c f u} / \mathbf{m L}\end{array}$ & $\begin{array}{c}\text { Initial Population } \\
\mathbf{1 0} \mathbf{c f u} / \mathbf{m L}\end{array}$ \\
\hline 80 & 3 & - & - & $58.5 \%$ & $60.9 \%$ \\
\hline 80 & 2 & 2 & 10 & $47.1 \%$ & $45.4 \%$ \\
\hline 80 & 1 & 2 & 10 & $3.1 \%$ & $2.1 \%$ \\
\hline 60 & 3 & - & - & $37.7 \%$ & $42.6 \%$ \\
\hline 60 & 3 & 2 & 10 & $26.9 \%$ & $30.2 \%$ \\
\hline 60 & 2 & 2 & 10 & $6.9 \%$ & $6.1 \%$ \\
\hline 60 & 1 & 2 & 10 & $0 \%$ & $2.2 \%$ \\
\hline
\end{tabular}

\subsubsection{Attenuation Effects}

The previous experiment, carried out with six strains, indicated that the loss of vitality was not derived from a loss of viability. Student's $t$-test $(\alpha=0.05)$ showed that there were significant differences between the vitality of the sonicated samples and that of the non-sonicated samples from the same population.

With the selected sonication conditions (60\% amplitude for a total period of $2 \mathrm{~min}$ with pulses of $2 \mathrm{~s}$ on $10 \mathrm{~s}$ off), variable attenuation was achieved among the different strains (Figure 5).

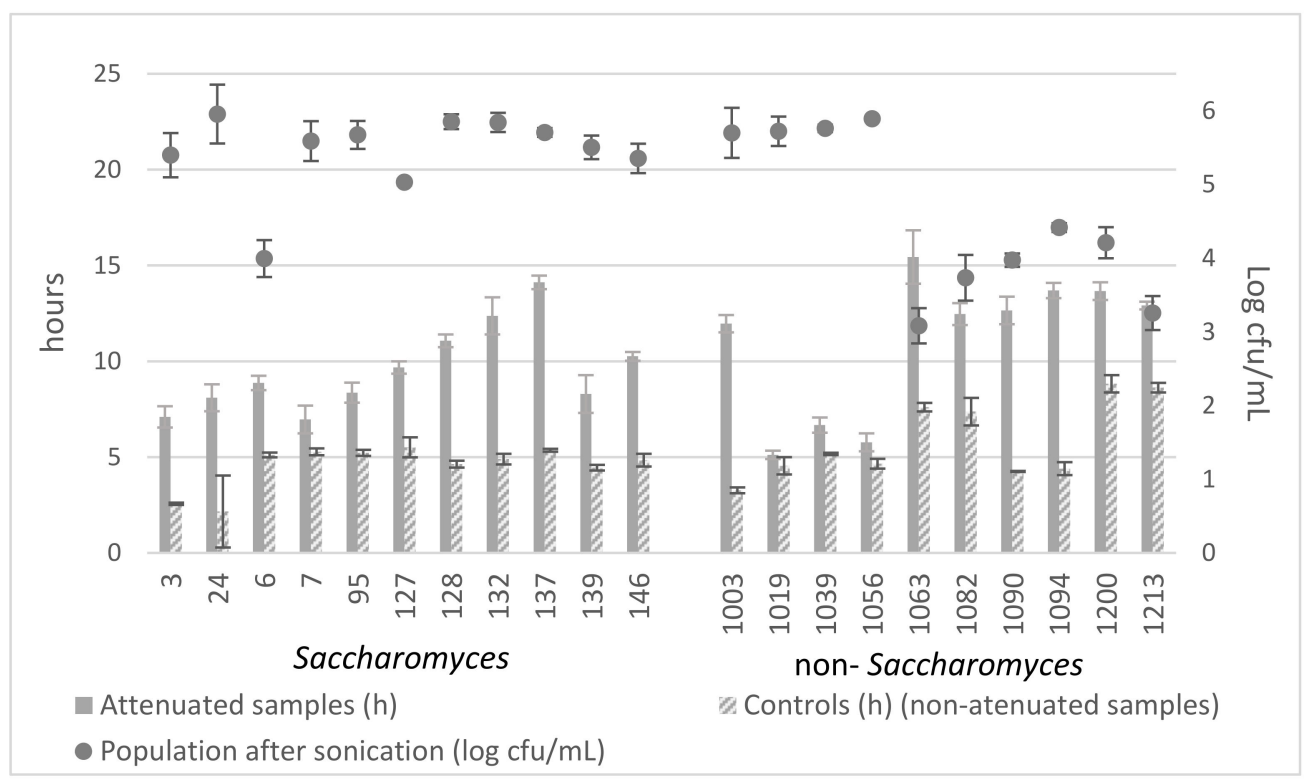

Figure 5. Yeast viability and vitality after the attenuation relative to the corresponding controls.

Overall, without subjecting the strains to sonication, the strains of Saccharomyces had a similar vitality (they started growing between $2.17 \mathrm{~h}$ and $5.51 \mathrm{~h}$ ), while for the non-Saccharomyces strains, there was more variation (between $3.27 \mathrm{~h}$ and $8.83 \mathrm{~h}$ ).

Comparing the final effect of attenuation on each strain $(\alpha=0.05, \mathrm{~F}=69.22$, Significance $=0.00$ ), it was observed that the strain with the lowest vitality was 1063 $(15.44 \mathrm{~h})$ with significant differences, followed by the strains 137 (14.05 h), 1094 (13.70 h), and $1200(13.67 \mathrm{~h})$, among which there were no significant differences. Even without sonication, strains 1063 and 1200 already showed low vitality at $7.61 \mathrm{~h}$ and $8.83 \mathrm{~h}$, respectively.

Comparing the sonicated samples with their corresponding controls (samples not subjected to sonication), a greater attenuation effect was achieved in strains 137, 1003, 1090, 
and $1094(8.69,8.70,8.40$, and 9.30, respectively) without significant differences between them $(\alpha=0.05, F=63.66$, Significance $=0.00)$.

Regarding viability, the strains of Saccharomyces were quite resistant. The loss of viability fluctuated between $0.76 \%$ and $16.18 \%$ with strain 6 being an outlier, with a loss of $33.43 \%$. Non-Saccharomyces yeasts were more susceptible to treatment. There were two groups; the most resistant $(1003,1019,1039$, and 1056) displayed percentages of loss in viability between $1.80 \%$ and $5.02 \%$, and the rest displayed percentages of between $26.42 \%$ and $49.11 \%$.

Therefore, based on a balance between minimum loss of viability and maximum final attenuation, the best strain is 132 , followed by 137 , both of them Saccharomyces.

\subsection{Selection of Strains}

To select the most promising yeast strains, a PCA analysis was carried out for both Saccharomyces and non-Saccharomyces strains. For the final decision, the results of the adhesion to Caco-2/TC7 cells test were also taken into account.

Table 5 shows the explained variance and the factor loadings, which describe the degree of correlation of the principal components with the functional traits examined. The analysis accounted for $77.61 \%$ of the total variability. The disposition of strains is represented in Figure 6, where there are four groups (two groups outline the behavior of the Saccharomyces, and the other two non-Saccharomyces) and three outliers. As a result of the PCA, five strains were selected as being representative of the whole population.

Table 5. Contributions of the highly correlated variables and their loadings in principal components $1,2,3,4$, and 5 .

\begin{tabular}{|c|c|c|c|c|}
\hline $\begin{array}{l}\text { Principal } \\
\text { Component }\end{array}$ & $\begin{array}{c}\text { Variance } \\
\text { Explained (\%) }\end{array}$ & $\begin{array}{c}\text { Total Variance } \\
(\%)\end{array}$ & $\begin{array}{c}\text { Most Highly } \\
\text { Correlated }\end{array}$ & Loading \\
\hline 1 & 27.38 & 27.38 & $\begin{array}{l}\text { Fluconazol PI } \\
\text { Canesten PI } \\
\text { Mycostatin TI } \\
\text { Ciclochem PI } \\
\text { Pectin }\end{array}$ & $\begin{array}{c}0.87 \\
0.80 \\
0.71 \\
-0.70 \\
-0.55\end{array}$ \\
\hline 2 & 20.38 & 47.77 & $\begin{array}{l}\text { Fluconazol TI } \\
\text { Raffinose } \\
\text { Canesten TI } \\
\text { Trehalose }\end{array}$ & $\begin{array}{c}0.81 \\
-0.80 \\
0.79 \\
-0.69\end{array}$ \\
\hline 3 & 11.34 & 59.11 & $\begin{array}{c}\text { ß-glucan } \\
\text { Xylan } \\
\text { Cellulose } \\
\text { DPPH } \\
\text { Attenuation } \\
\text { vital. }\end{array}$ & $\begin{array}{c}0.79 \\
0.78 \\
0.77 \\
-0.73 \\
-0.56\end{array}$ \\
\hline 4 & 10.04 & 69.15 & $\begin{array}{c}\text { Ciclochem TI } \\
\text { Cellobiose } \\
\text { Melibiose }\end{array}$ & $\begin{array}{c}0.85 \\
0.72 \\
-0.55\end{array}$ \\
\hline 5 & 8.46 & 77.61 & $\begin{array}{l}\text { Cholesterol } \\
\text { Attenuation }\end{array}$ & $\begin{array}{c}0.88 \\
-0.62\end{array}$ \\
\hline
\end{tabular}

PI: partian inhibition; TI: total inhibition. 


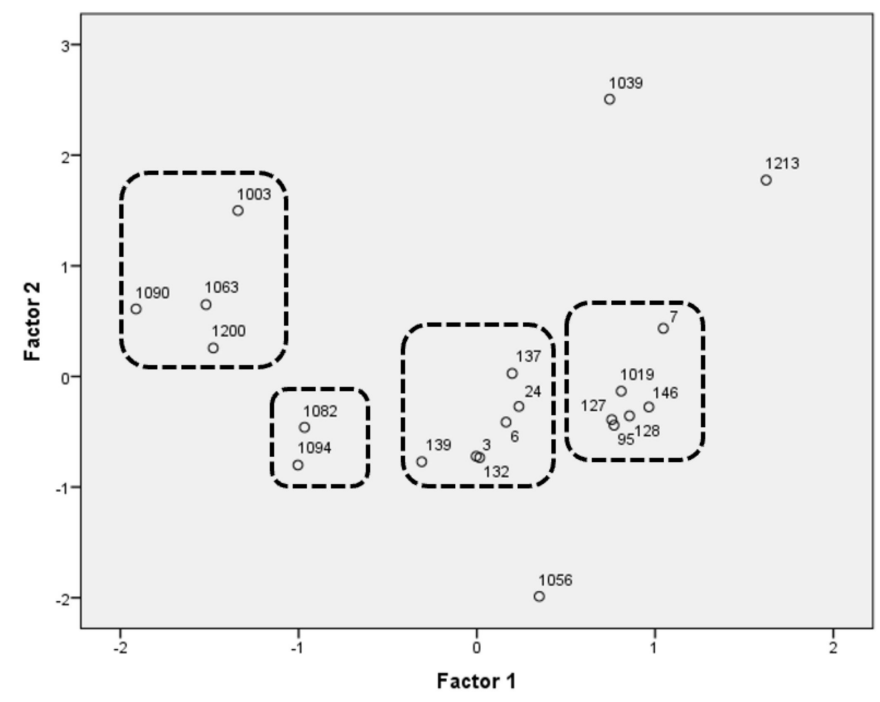

Figure 6. Principal component analysis run on the fitting parameters of the functional characteristics. Case projection (yeast distribution as a function of the variables). Dotted line represents groups of strains with the similar profile.

Strain 3, from the group in the center of the graph, was chosen thanks to its antioxidant properties, its enzymatic activities, and the high percentage of adhesion presented. Furthermore, in previous studies, this strain was used as a positive control thanks to its resistance to gastrointestinal conditions. Strain 146, from the group that includes the rest of the Saccharomyces, and strain 1039, an outlier, were chosen because of their antimycotic resistance and their relationship with the prebiotics studied (xylan or $\beta$-glucan). Moreover, strain 1039 also presented the best adhesion results. On the other hand, strains 1056 and 1094 were selected for their roles in the use of raffinose and trehalose. Strain 1056 also presented the lowest losses of viability and vitality after the attenuation process.

\section{Conclusions}

An adequate probiotic strain for human consumption must be chosen, not only for its probiotic properties, but also for other biotechnological features, depending on the purpose of the final product. This work investigated the functional and biotechnological capacities of twenty yeasts with probiotic character, and observed their behavior after an attenuation process that would allow the yeast to be safely incorporated into a food or supplement.

The strains with the best results in each test have been highlighted, so that the most appropriate strains can be chosen for specific uses. Five best strains were chosen based on PCA, taking into account the balance between all of the tests carried out. The strains are two strains of H. osmophila (1056 and 1094), one of L. thermotolerans (1039), and two of S. cerevisiae ( 3 and 146). Their results demonstrate their potential as health-promoting probiotics.

Author Contributions: Conceptualization, A.B.P. and M.A.-V.; methodology, P.F.-P. and M.A.-V.; formal analysis, P.F.-P. and C.P.; resources, M.A.-V. and A.B.P.; writing—original draft preparation, P.F.P.; writing-review and editing, P.F.-P. and M.A.-V.; visualization, A.B.P.; supervision, A.B.P.; funding acquisition, M.A.-V. All authors have read and agreed to the published version of the manuscript.

Funding: This study was supported by the project from "Junta de Comunidades de Castilla LaMancha (SBPLY/17/180501/000528)".

Institutional Review Board Statement: Not applicable.

Informed Consent Statement: Not applicable.

Data Availability Statement: Not applicable. 
Acknowledgments: The authors wish to express their gratitude to Alberto Dávalos (Epigenetics of Lipid Metabolism Group, IMDEA Food, Madrid) and Emma Burgos-Ramos (Área de Bioquímica, Universidad de Castilla-La Mancha, Toledo) for providing the Caco-2 cells.

Conflicts of Interest: The authors declare no conflict of interest.

\section{References}

1. Binetti, A.; Carrasco, M.; Reinheimer, J.; Suárez, V. Yeasts from autochthonous cheese starters: Technological and functional properties. J. Appl. Microbiol. 2013, 115, 434-444. [CrossRef] [PubMed]

2. Chelliah, R.; Ramakrishnan, S.R.; Prabhu, P.R.; Antony, U. Evaluation of antimicrobial activity and probiotic properties of wild-strainPichia kudriavzeviiisolated from frozenidlibatter. Yeast 2016, 33, 385-401. [CrossRef]

3. Silva, T.; Reto, M.; Sol, M.; Peito, A.; Peres, C.M.; Peres, C.; Malcata, F.X. Characterization of yeasts from Portuguese brined olives, with a focus on their potentially probiotic behavior. LWT-Food Sci. Technol. 2011, 44, 1349-1354. [CrossRef]

4. Ogunremi, O.; Sanni, A.; Agrawal, R. Probiotic potentials of yeasts isolated from some cereal-based Nigerian traditional fermented food products. J. Appl. Microbiol. 2015, 119, 797-808. [CrossRef] [PubMed]

5. Adams, M. Safety of industrial lactic acid bacteria. J. Biotechnol. 1999, 68, 171-178. [CrossRef]

6. Moslehi-Jenabian, S.; Lindegaard, L.; Jespersen, L. Beneficial Effects of Probiotic and Food Borne Yeasts on Human Health. Nutrients 2010, 2, 449-473. [CrossRef] [PubMed]

7. Meriggi, N.; Di Paola, M.; Vitali, F.; Rivero, D.; Cappa, F.; Turillazzi, F.; Gori, A.; Dapporto, L.; Beani, L.; Turillazzi, S.; et al. Saccharomyces cerevisiae Induces Immune Enhancing and Shapes Gut Microbiota in Social Wasps. Front. Microbiol. 2019, 10, 2320. [CrossRef]

8. Li, Y.; Sadiq, F.A.; Liu, T.; Chen, J.; He, G. Purification and identification of novel peptides with inhibitory effects against angiotensin I-converting enzyme and optimization of process conditions in milk fermented with the yeast Kluyveromyces marxianus. J. Funct. Foods 2015, 16, 278-288. [CrossRef]

9. FAO; WHO. Guidelines for the Evaluation of Probiotics in Food. In Food and Agriculture Organization of the United Nations and World Health Organization Working Group Report; FAO: Rome, Italy; WHO: Geneva, Switzerland, 2002.

10. Salminen, S.; von Wright, A.; Morelli, L.; Marteau, P.; Brassart, D.; de Vos, W.M.; Fondén, R.; Saxelin, M.; Collins, K.; Mogensen, G.; et al. Demonstration of safety of probiotics-A review. Int. J. Food Microbiol. 1998, 44, 93-106. [CrossRef]

11. Foligné, B.; Daniel, C.; Pot, B. Probiotics from research to market: The possibilities, risks and challenges. Curr. Opin. Microbiol. 2013, 16, 284-292. [CrossRef]

12. Manson, J.E.; Tosteson, H.; Ridker, P.M.; Satterfield, S.; Hebert, P.; O'Connor, G.T.; Buring, J.E.; Hennekens, C.H. The Primary Prevention of Myocardial Infarction. N. Engl. J. Med. 1992, 326, 1406-1416. [CrossRef]

13. Nita, M.; Grzybowski, A. The Role of the Reactive Oxygen Species and Oxidative Stress in the Pathomechanism of the Age-Related Ocular Diseases and Other Pathologies of the Anterior and Posterior Eye Segments in Adults. Oxidative Med. Cell. Longev. 2016, 2016, 1-23. [CrossRef] [PubMed]

14. Suárez, J.E. Microbiota autóctona, probióticos y prebióticos. Nutr. Hosp. 2015, 31, 3-9. [PubMed]

15. Bevilacqua, A.; Casanova, F.P.; Petruzzi, L.; Sinigaglia, M.; Corbo, M.R. Using physical approaches for the attenuation of lactic acid bacteria in an organic rice beverage. Food Microbiol. 2016, 53, 1-8. [CrossRef]

16. Dai, C.; Xiong, F.; He, R.; Zhang, W.; Ma, H. Effects of low-intensity ultrasound on the growth, cell membrane permeability and ethanol tolerance of Saccharomyces cerevisiae. Ultrason. Sonochem. 2017, 36, 191-197. [CrossRef] [PubMed]

17. Samani, B.H.; Khoshtaghaza, M.H.; Lorigooini, Z.; Minaei, S.; Zareiforoush, H. Analysis of the combinative effect of ultrasound and microwave power on Saccharomyces cerevisiae in orange juice processing. Innov. Food Sci. Emerg. Technol. 2015, 32, 110-115. [CrossRef]

18. Arévalo-Villena, M.; Fernández-Pacheco, P.; Castillo, N.; Bevilacqua, A.; Briones, A. Probiotic yeast. Set up of a method for screening. LWT-Food Sci. Technol. 2018, 89, 657-665. [CrossRef]

19. Fernandez-Pacheco, P.; Arévalo-Villena, M.; Bevilacqua, A.; Corbo, M.R.; Pérez, A.B. Probiotic characteristics in Saccharomyces cerevisiae strains: Properties for application in food industries. LWT-Food Sci. Technol. 2018, 97, 332-340. [CrossRef]

20. Fernández-Pacheco Rodríguez, P.; Arévalo-Villena, M.; Zaparoli Rosa, I.; Briones Pérez, A. Selection of potential non-Sacharomyces probiotic yeasts from food origin by a step-by-step approach. Food Res. Int. 2018, 112, 143-151. [CrossRef] [PubMed]

21. Fernández-Pacheco, P.; Cueva, C.; Arévalo-Villena, M.; Moreno-Arribas, M.V.; Pérez, A.B. Saccharomyces cerevisiae and Hanseniaspora osmophila strains as yeast active cultures for potential probiotic applications. Food Funct. 2019, 10, 4924-4931. [CrossRef]

22. Rodríguez, J.M. Probióticos: Del laboratorio al consumidor. Nutr. Hosp. 2015, 31, 33-47. [PubMed]

23. Diosma, G.; Romanin, D.E.; Rey-Burusco, M.F.; Londero, A.; Garrote, G.L. Yeasts from kefir grains: Isolation, identification, and probiotic characterization. World J. Microbiol. Biotechnol. 2014, 30, 43-53. [CrossRef]

24. Golowczyc, M.; Mobili, P.; Garrote, G.; Abraham, A.; De Antoni, G. Protective action of Lactobacillus kefir carrying S-layer protein against Salmonella enterica serovar Enteritidis. Int. J. Food Microbiol. 2007, 118, 264-273. [CrossRef] [PubMed]

25. Kumar, M.; Nagpal, R.; Kumar, R.; Hemalatha, R.; Verma, V.; Kumar, A.; Chakraborty, C.; Singh, B.; Marotta, F.; Jain, S.; et al. Cholesterol-Lowering Probiotics as Potential Biotherapeutics for Metabolic Diseases. Exp. Diabetes Res. 2012, $2012,1-14$. [CrossRef] [PubMed]

26. Gilliland, S.E.; Nelson, C.R.; Maxwell, C. Assimilation of cholesterol by Lactobacillus acidophilus. Appl. Environ. Microbiol. 1985, 49, 377-381. [CrossRef] 
27. Brand-Williams, W.; Cuvelier, M.; Berset, C. Use of a free radical method to evaluate antioxidant activity. LWT-Food Sci. Technol. 1995, 28, 25-30. [CrossRef]

28. Trotta, F.; Caldini, G.; Dominici, L.; Federici, E.; Tofalo, R.; Schirone, M.; Corsetti, A.; Suzzi, G.; Cenci, G. Food borne yeasts as DNA-bioprotective agents against model genotoxins. Int. J. Food Microbiol. 2012, 153, 275-280. [CrossRef]

29. Whittenbury, R. Hydrogen Peroxide Formation and Catalase Activity in the Lactic Acid Bacteria. Microbiology 1964, 35, 13-26. [CrossRef] [PubMed]

30. Kumura, H.; Tanoue, Y.; Tsukahara, M.; Tanaka, T.; Shimazaki, K. Screening of Dairy Yeast Strains for Probiotic Applications. J. Dairy Sci. 2004, 87, 4050-4056. [CrossRef]

31. Kurtzman, C.P.; Fell, J.W.; Boekhout, T. The Yeasts: A Taxonomic Study, 5th ed.; Elsevier: San Diego, CA, USA, 2011 ; Volume 2.

32. Psomas, E.; Fletouris, D.; Litopoulou-Tzanetaki, E.; Tzanetakis, N. Assimilation of Cholesterol by Yeast Strains Isolated from Infant Feces and Feta Cheese. J. Dairy Sci. 2003, 86, 3416-3422. [CrossRef]

33. Chen, L.-S.; Ma, Y.; Maubois, J.-L.; He, S.-H.; Li, H.-M.; Chen, L.-J. Screening for the potential probiotic yeast strains from raw milk to assimilate cholesterol. Dairy Sci. Technol. 2010, 90, 537-548. [CrossRef]

34. Psomas, E.; Andrighetto, C.; Litopoulou-Tzanetaki, E.; Lombardi, A.; Tzanetakis, N. Some probiotic properties of yeast isolates from infant faeces and Feta cheese. Int. J. Food Microbiol. 2001, 69, 125-133. [CrossRef]

35. Lee, N.K.; Yun, C.W.; Kim, S.W.; Chang, H.I.; Kang, C.W.; Paik, H.D. Screening of Lactobacilli derived from chicken feces and partial characterization of Lactobacillus acidophilus A12 as an animal probiotic. J. Microbiol. Biotechnol. 2008, 18, 338-342. [PubMed]

36. Bilski, J.; Mazur-Bialy, A.; Wojcik, D.; Zahradnik-Bilska, J.; Brzozowski, B.; Magierowski, M.; Mach, T.; Magierowska, K.; Brzozowski, T. The Role of Intestinal Alkaline Phosphatase in Inflammatory Disorders of Gastrointestinal Tract. Mediat. Inflamm. 2017, 2017, 1-9. [CrossRef]

37. De Lima, M.D.S.F.; De Souza, K.M.S.; Albuquerque, W.W.C.; Teixeira, J.A.C.; Cavalcanti, M.T.H.; Porto, A.L.F. Saccharomyces cerevisiae from Brazilian kefir-fermented milk: An in vitro evaluation of probiotic properties. Microb. Pathog. 2017, 110, 670-677. [CrossRef]

38. França, M.; Panek, A.; Eleutherio, E. Oxidative stress and its effects during dehydration. Comp. Biochem. Physiol. Part A Mol. Integr. Physiol. 2007, 146, 621-631. [CrossRef] [PubMed]

39. Herrero, E.; Ros, J.; Bellí, G.; Cabiscol, E. Redox control and oxidative stress in yeast cells. Biochim. Biophys. Acta (BBA)-Gen. Subj. 2008, 1780, 1217-1235. [CrossRef] [PubMed]

40. Tomusiak-Plebanek, A.; Heczko, P.; Skowron, B.; Baranowska, A.; Okoń, K.; Thor, P.J.; Strus, M. Lactobacilli with superoxide dismutase-like or catalase activity are more effective in alleviating inflammation in an inflammatory bowel disease mouse model. Drug Des. Dev. Ther. 2018, 12, 3221. [CrossRef] [PubMed] 